Endocrinol. Japon. 1986, 33 (6), 743-749

\title{
Effect of a Single Administration of Somatostatin Analogue (SMS 201-995) on GH, TSH and Insulin Secretion in Patients with Acromegaly
}

\author{
Reiko HoriKaWA, Kazue TAKANo, Naomi HIZUKA, Kumiko ASAKAWA, \\ TAmotsu SHIBASAKI, AKITSUGU MASUDA and KazUo SHIZUME
}

\author{
Department of Medicine, Institute of Clinical Endocrinology, \\ Tokyo Women's Medical College, 8-1 Kawada-cho, \\ Shinjuku-ku, Tokyo 162, Japan
}

\begin{abstract}
The effect of a long-acting somatostatin analogue SMS 201-995 on GH secretion was investigated. Eleven acromegalic patients received a single dose of 50 $\mu \mathrm{g}$ SMS 201-995 administered subcutaneously, and plasma GH, IGF-I, GRF, TSH, IRI and blood glucose were determined at regular intervals. Nine of 11 patients had elevated basal plasma GH levels above $5 \mathrm{ng} / \mathrm{ml}$. In all patients, plasma GH levels fell immediately from $39.5 \pm 17.3 \mathrm{ng} / \mathrm{ml}$ (mean \pm SEM) to $4.3 \pm 1.6 \mathrm{ng} / \mathrm{ml}(\mathrm{P}<0.05)$ with a maximal inhibition of $82.9 \pm 3.3 \%$ of the basal levels and the suppression persisted for about $6 \mathrm{~h}$ of the observation period.

IGF-I and GRF levels were not apparently altered. TSH and IRI levels also rapidly fell. Blood glucose levels fell slightly by $0.5 \mathrm{~h}$. Ten of 11 patients had pain at injection sites. Except for this, no side effects were observed. Our results show that the new somatostatin analogue SMS 201-995 may inhibit GH hypersecretion in acromegalic patients for significant periods, suggesting that this agent can be a useful clinical tool for the treatment of acromegaly.
\end{abstract}

A long-acting somatostatin analogue (SMS 201-995; Sandoz, Basel, Switzerland) was developed (Bauer et al., $1982 \mathrm{a}, \mathrm{b}$ ) and became available for the treatment of acromegaly recently. The subcutaneous administration of this peptide has produced a clear reduction in plasma $\mathrm{GH}$ of long duration in acromegalic patients including those whose plasma GH levels were not suppressed below $5 \mathrm{ng} / \mathrm{ml}$ by any other treatment. This analogue was reported to show less rebound hypersecretion of $\mathrm{GH}$

Received February 7, 1986 than the natural somatostatin (Besser et al., 1974; Ch'ng et al., 1985; Lamberts et al., 1985 a, b; Plewe et al., 1984 a).

We have studied here the effect of a single subcutaneous administration of $50 \mu \mathrm{g}$ SMS 201-995 in 11 acromegalic patients to see if this new drug could be suitable for the clinical management of acromegaly.

\section{Materials and Methods}

The patients with acromegaly consisted of 3 males and 8 females aged 34-68 years. The 
Table 1. Clinical and laboratory data in 11 patients with acromegaly

\begin{tabular}{|c|c|c|c|c|c|c|}
\hline $\begin{array}{l}\text { Patient } \\
\text { No. }\end{array}$ & $\begin{array}{l}\text { Age } \\
\text { (ys) }\end{array}$ & $\begin{array}{c}\mathrm{Sex} \\
(\mathrm{M} / \mathrm{F})\end{array}$ & $\begin{array}{l}\text { Previous } \\
\text { Treatment }\end{array}$ & $\begin{array}{l}\text { Present } \\
\text { Treatment }\end{array}$ & $\begin{array}{c}\text { Basal GH } \\
\mathrm{ng} / \mathrm{ml}\end{array}$ & $\begin{array}{l}\text { Basal IGF-I } \\
\mathrm{ng} / \mathrm{ml}\end{array}$ \\
\hline $1 *$ & 34 & $F$ & $\mathrm{Op}$ & $\mathrm{BR}+\mathrm{T}_{4}+\mathrm{F}$ & 60.6 & 64.8 \\
\hline 2 & 34 & $\mathrm{~F}$ & $\mathrm{Op}+\mathrm{Rx}$ & BR & 20.0 & 64.0 \\
\hline $3 *$ & 35 & M & & $\mathrm{BR}$ & 81.0 & 205.0 \\
\hline 4 & 44 & $\mathrm{~F}$ & $\mathrm{Op}+\mathrm{Rx}$ & $\mathrm{T}_{4}+\mathrm{F}$ & 195.0 & 160.0 \\
\hline $5^{*}$ & 52 & $\mathrm{~F}$ & $\mathrm{Op}+\mathrm{Rx}+\mathrm{BR}$ & $\begin{array}{l}\text { Lisuride }{ }^{\circledR}+ \\
\mathrm{T}_{4}+\mathrm{F}\end{array}$ & 30.0 & 222.5 \\
\hline 6 & 54 & $\mathbf{M}$ & BR & & 5.0 & 172.0 \\
\hline 7 & 54 & $\mathrm{~F}$ & & BR & 19.5 & 126.0 \\
\hline 8 & 66 & M & & BR & 8.1 & 116.0 \\
\hline 9 & 66 & F & Op & PTU & 1.1 & 110.0 \\
\hline $10^{*}$ & 66 & $\mathrm{~F}$ & $O p$ & & 5.0 & 27.2 \\
\hline 11 & 68 & $\mathrm{~F}$ & $\mathrm{BR}$ & & 9.5 & 77.2 \\
\hline Mean & 52.1 & & & & 39.5 & 128.0 \\
\hline SD & 13.6 & & & & 57.4 & 62.5 \\
\hline SEM & 4.1 & & & & 17.3 & 19.8 \\
\hline
\end{tabular}

Transsphenoidal surgery (Op), Irradiation (Rx), Bromocriptine (BR), Thyroxine $\left(\mathrm{T}_{4}\right)$, Hydrocortisone (F), Propylthiouracil (PTU). $\quad *$ Diabetic Patients.

diagnost:c criteria were nonsuppressibility of elevated plasma $\mathrm{GH}$ below $5 \mathrm{ng} / \mathrm{ml}$ in response to an oral $75 \mathrm{~g}$ glucose load in addition to the clinical picture. One patient (case 9) had hyperthyro:dism with a high level of TSH and was suspected to have combined TSH producing pituitary tumor. Informed consent was obtained from each patient and the experimental protocol was approved by the Human Subjects Investigation Committee of our department. The clinical and laboratory data for these patients are shown in Table 1. Six of 11 patients had previously been treated by transsphenoidal surgery and 3 of them had additional irradiation. Five of the rest have been treated with bromocriptine. Basal plasma $\mathrm{GH}$ levels ranged $1.1-195.0 \mathrm{ng} / \mathrm{ml}$ with a mean of $39.5 \pm 17.3$ (mean \pm SEM) $\mathrm{ng} / \mathrm{ml}$. Plasma IGF-I levels varied between 27.2 and $222.5 \mathrm{ng} /$ $\mathrm{ml}$ with a mean of $128.0 \pm 19.8 \mathrm{ng} / \mathrm{ml}$. Bromocriptine and Lisuride ${ }^{\circledR}$ therapy was withdrawn the day before the investigation.

All patients were studied under resting conditions. They received $50 \mu \mathrm{g}$ SMS 201-995 subcutaneously around $0830 \mathrm{~h}$ to $0930 \mathrm{~h}$. Each subject was fitted with a heparin-locked cannula in a forearm vein for drawing blood. Blood samples were taken at $0,0.5,1,1.5,2,3,4,5$ and $6 \mathrm{~h}$ after injection for the determination of plasma $\mathrm{GH}$, insulin-like growth factor I (IGF-I), GRF, TSH, immunoreactive insulin (IRI) and blood glucose.
In one patient blood samples were taken in addition at 8 and $12 \mathrm{~h}$. Four hours after injection, the cannulae were withdrawn and the patients had a meal provided by the hospital.

SMS 201-995 was kindly provided by Sandoz (Basel, Switzerland). Plasma GH was determined by a double antibody radioimmunoassay (RIA) generously provided by the National Hormone and Pituitary Program of NIADDK, NIH (hGH : AFP-4793B; antibody: AFP-97720133). Plasma GH levels below $1 \mathrm{ng} / \mathrm{ml}$ were measured by immunoradiometric assay kit (IRMA; Boots-Celltech Diagnostic Limited, Berkshire, U.K.). The minimal plasma GH detected by IRMA was $0.05 \mathrm{ng} / \mathrm{ml}$. Plasma IGF-I was measured by RIA (Miyakawa et al., 1986) with modification of the method of Furlanetto et al. (1977). The normal range for human adults and the range for hypopituitarism in this assay were $9.2-35 \mathrm{ng} / \mathrm{ml}$ and $<1-6.1 \mathrm{ng} / \mathrm{ml}$, respectively. Plasma GRF was determined by RIA described by Shibasaki et al. (1984). TSH was determined by immunoradiometric assay (IRMA; BootsCelltech Diagnostic Limited, Berkshire, U. K.) provided by Special Reference Laboratory (Tokyo, Japan). The minimal detectable serum TSH was $0.1 \mu \mathrm{U} / \mathrm{ml}$. Serum IRI was measured with a commercially available RIA kit (Dinabot Co., Ltd.). Blood glucose was measured by the glucose-oxidation method. 
Paired $t$-test and Student's $t$-test was used to determine the statistical significance.

\section{Results}

Plasma GH levels after $50 \mu \mathrm{g}$ subcutaneous administration of SMS 201-995 are shown in
Table 2 and Fig. 1. In all patients, plasma $\mathrm{GH}$ levels rapidly fell from $39.5 \pm 17.3 \mathrm{ng} / \mathrm{ml}$ $($ mean $\pm S E M)$ to $4.3 \pm 1.6 \mathrm{ng} / \mathrm{ml} \quad(\mathrm{P}<0.05)$ after injection. The maximal inhibition of the $\mathrm{GH}$ level was reached at $2-5 \mathrm{~h}$ with a mean inhibition of $82.9 \pm 3.3 \%$ of the basal level, and the GH level was still suppressed to $68.1 \pm 7.2 \%$ at $6 \mathrm{~h}$ after injection. In

Table 2. Plasma GH (ng/ml) levels after $50 \mu \mathrm{g}$ sc administration of SMS 201-995

\begin{tabular}{|c|c|c|c|c|c|c|c|c|c|}
\hline \multirow{2}{*}{$\begin{array}{l}\text { Patient } \\
\text { No. }\end{array}$} & \multicolumn{9}{|c|}{ Hours after SMS 201-995 Administration } \\
\hline & 0 & 0.5 & 1 & 1.5 & 2 & 3 & 4 & 5 & $6 \mathrm{~h}$ \\
\hline 1 & 60.6 & 32.8 & 16.2 & 8.8 & 5.7 & - & 4.3 & - & 9.8 \\
\hline 2 & 20 & 10.2 & 5.1 & 4.6 & 3.3 & 4.7 & 3.2 & 4.5 & 4.7 \\
\hline 3 & 81 & 32 & 20 & 12.1 & 6.4 & 4.5 & 6.4 & 11.1 & 19.3 \\
\hline 4 & 195 & 85 & 57.5 & 37 & 19 & 27.5 & 25.5 & 20.5 & 26.5 \\
\hline 5 & 30 & 18 & 9.5 & 5.5 & 4.6 & 3.2 & 2.6 & 5.8 & 6.9 \\
\hline 6 & 5 & 2.7 & 1.7 & 1.3 & 0.7 & 0.7 & 0.9 & 1.1 & 1.2 \\
\hline 7 & 19.5 & 9.2 & 6 & 4.5 & 3.5 & 3.4 & 3.5 & 3.2 & - \\
\hline 8 & 8.1 & 5.3 & 3.4 & 2.7 & 2.3 & 2.4 & 2.5 & 4.7 & 5.8 \\
\hline 9 & 1.1 & 0.6 & 0.5 & 0.5 & 0.5 & 0.4 & 0.5 & 0.7 & 0.7 \\
\hline 10 & 5.0 & 2.0 & 1.2 & 0.8 & 0.7 & 0.7 & 1.1 & 1.1 & 2.7 \\
\hline 11 & 9.5 & 4.3 & 2.3 & 1.4 & 0.9 & 0.7 & 0.6 & 0.6 & 0.6 \\
\hline Mean & 39.5 & 18.4 & 11.2 & 7.2 & 4.3 & 4.8 & 4.7 & 5.3 & 7.8 \\
\hline SD & 57.4 & 24.9 & 16.6 & 10.5 & 5.3 & 8.1 & 7.1 & 6.2 & 8.1 \\
\hline SEM & 17.3 & 7.5 & 5.0 & 3.2 & 1.6 & 2.6 & 2.2 & 2.0 & 2.7 \\
\hline
\end{tabular}

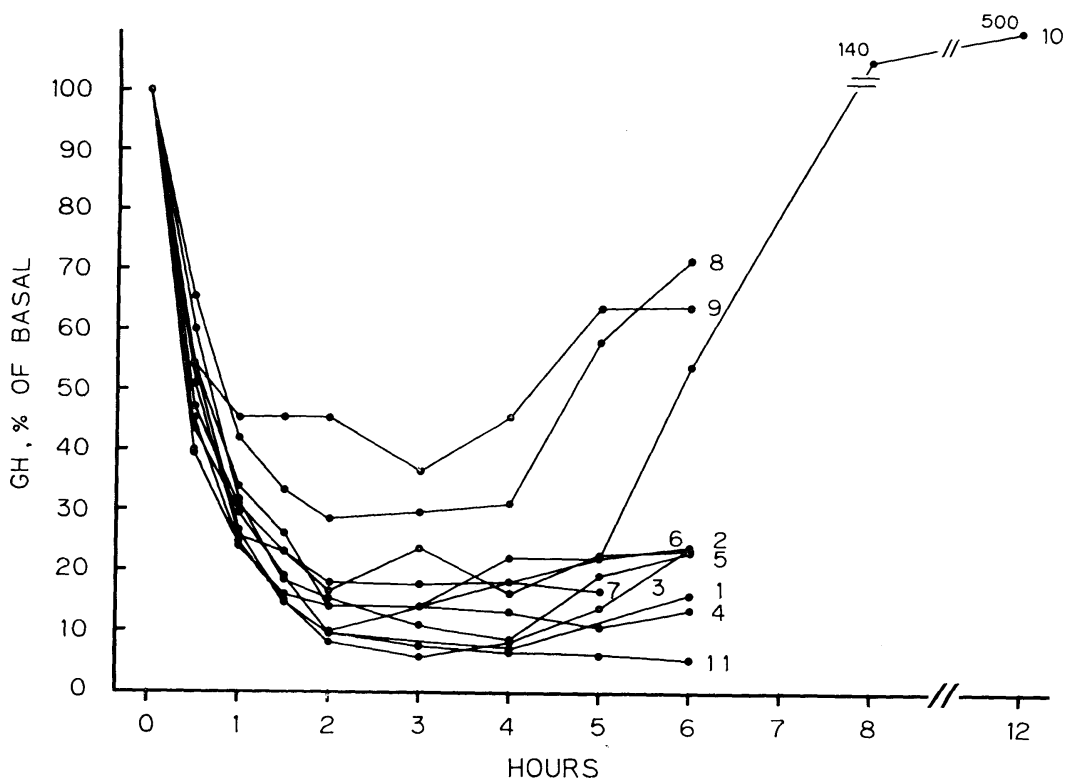

Fig. 1. Percent decrease in $\mathrm{GH}$ after a single administration of SMS 201-995 in acromegalic. The numbers in the figure correspond to the patients listed in Table 1. 

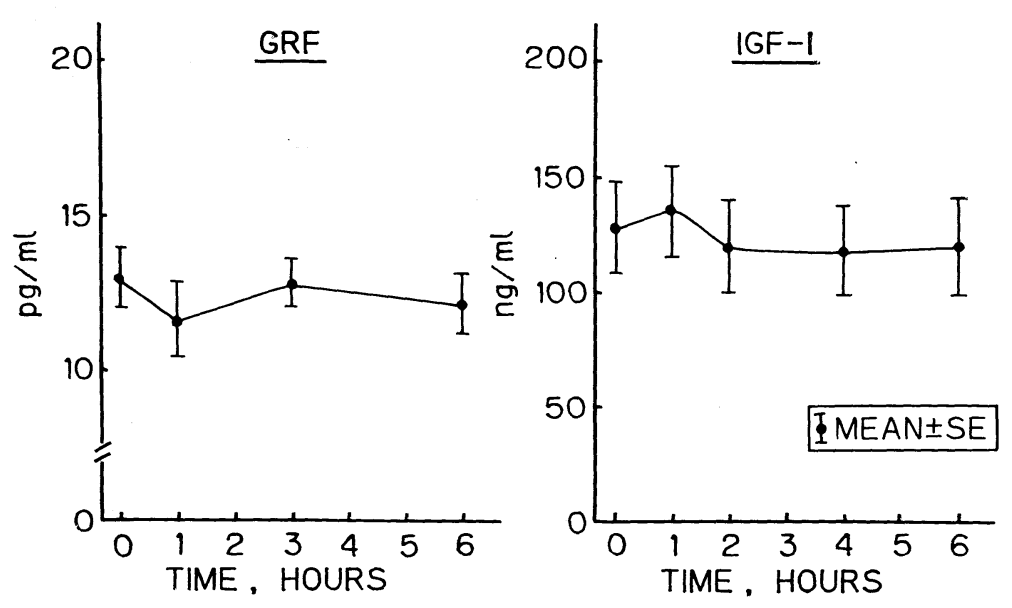

Fig. 2. Plasma GRF and IGF-I levels after a single administration of SMS 201-995 in 10 acromegalic patients.

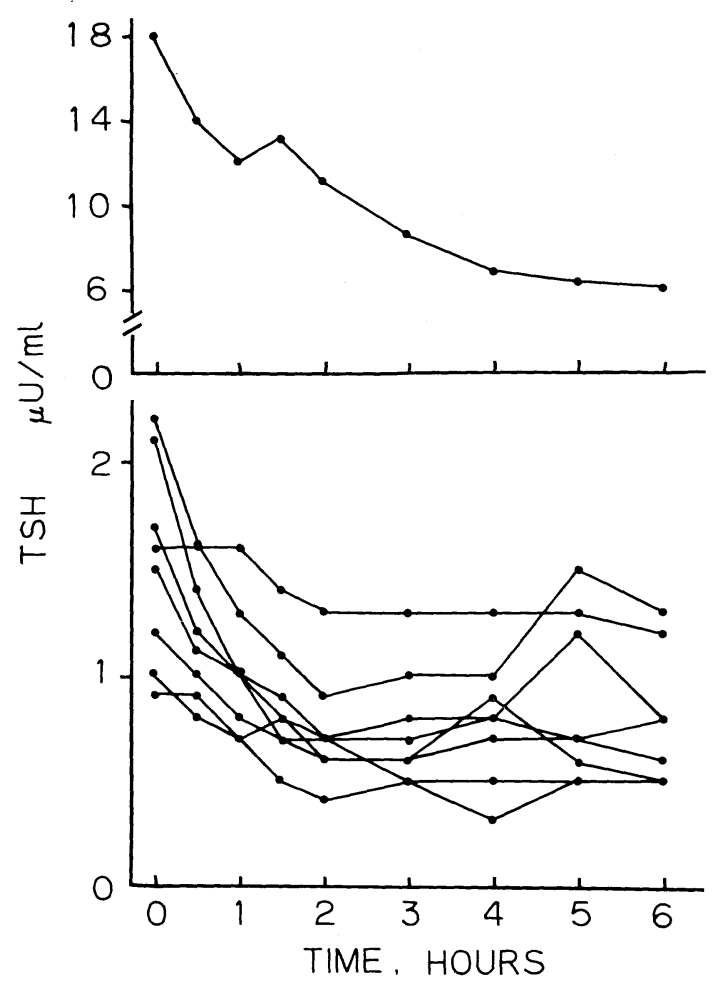

Fig. 3. Serum TSH levels after a single administration of SMS 201-995 in 9 acromegalic patients. one patient (No. 10) the GH level was followed for $12 \mathrm{~h}$. In this case, the GH levels fell from $5 \mathrm{ng} / \mathrm{ml}$ to $0.7 \mathrm{ng} / \mathrm{ml}$ within $2 \mathrm{~h}$ and rose to 7 and $25 \mathrm{ng} / \mathrm{ml}$ at 8 and $12 \mathrm{~h}$ after injection, respectively.

Plasma GRF and IGF-I levels after SMS 201-995 administration are shown in Fig. 2. IGF-I and GRF, with a basal concentration of $128.0 \pm 19.8 \mathrm{ng} / \mathrm{ml}$ and $12.9 \pm 1.0 \mathrm{pg} / \mathrm{ml}$, respectively, showed no significant change.

Serum TSH levels after SMS 201-995 administration are shown in Fig. 3. The serum TSH level was suppressed to about $50 \%$ of the basal level for $2-4 \mathrm{~h}$ after injection. One patient (No. 9) with high basal TSH level showed a significant reduction in TSH from $18.0 \mu \mathrm{U} / \mathrm{ml}$ to $6.0 \mu \mathrm{U} / \mathrm{ml}$ at $6 \mathrm{~h}$.

Serum IRI and blood glucose levels after SMS 201-995 administration are shown in Fig. 4. The IRI level immediately fell from $26.2 \pm 6.5 \mu \mathrm{U} / \mathrm{ml}$ to $7.1 \pm 1.2 \mu \mathrm{U} / \mathrm{ml}$ and was lowest at $0.5 \mathrm{~h}$ after injection. IRI levels gradually rose after $2 \mathrm{~h}$, but were suppressed to $44.6 \pm 4.1 \%$ of basal levels at $4 \mathrm{~h}$ after injection. Blood glucose levels did not change significantly.

Ten of 11 patients complained of pain at the injection site, which persisted for a few minutes. No tumor or redness has remained at the site. No other side effects were observed. 


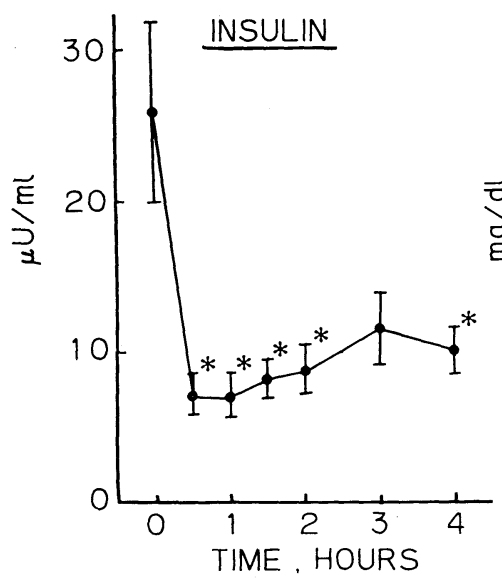

\section{Discussion}

After a single subcutaneous administration of $50 \mu \mathrm{g}$ SMS 201-995, plasma $\mathrm{GH}$ levels were strongly suppressed below $5 \mathrm{ng} /$ $\mathrm{ml}$ up to $6 \mathrm{~h}$ in 10 of 11 patients, whereas one patient (No. 4), whose basal GH level was $195 \mathrm{ng} / \mathrm{ml}$ had a minimum $\mathrm{GH}$ value of $20.5 \mathrm{ng} / \mathrm{ml}$, showing about a $90 \%$ reduction of the initial level. These results were compatible with the results of other workers (Althoff et al., 1984; Ch'ng et al., 1985; Mayer and Tillil, 1984; Lamberts et al., 1985 a, b; Plewe et al., 1984 a, b). This dose of $50 \mu \mathrm{g}$ SMS 201-995 corresponded to $0.44-1.06 \mu \mathrm{g} / \mathrm{kg}$ body weight in each patient. There seemed to be no relationship between the inhibition of $\mathrm{GH}$ secretion and the SMS 201-995 dose per body weight used.

No acute effect of SMS 201-995 on plasma IGF-I was observed. These data suggest that there is no direct inhibitory effect of SMS 201-995 on IGF-I secretion. Plewe et al. (1984 c, d) reported that IGF-I levels were reduced with three times a day subcutaneous injection of $50 \mu \mathrm{g}$ SMS 201995 over a 3-day period. More recently, Lamberts et al. (1985a) reported that after long term treatment, plasma IGF-I levels were significantly decreased in 4 acromegalic patients. As these reports have shown, long term administration of SMS 201-995 is necessary to obtain a decrease in IGF-I.

Plasma GRF levels were not altered during $6 \mathrm{~h}$ of investigation. A single injection of $50 \mu \mathrm{g}$ SMS 201-995 seems to have no effect on GRF secretion. On the other hand, Bloom et al. (1984) and Von Werder et al. (1984) reported that chronic administration of SMS 201-995 was effective in lowering plasma GRF levels in patients with GRF-producing tumors.

Serum TSH levels were suppressed in all patients including one patient (No. 9) who had a high basal TSH level. This result shows that the SMS 201-995 administration is also effective in reducing hypersecretion of TSH.

The suppression by SMS 201-995 of insulin secretion in our acromegalic patients was strong and continued for up to $4 \mathrm{~h}$ of the study period while the blood glucose did not change significantly, but had decreased slightly by $30 \mathrm{~min}$ after SMS 201995 injection and gradually increased by $4 \mathrm{~h}$. Blood glucose is regulated by many factors such as insulin, glucagon, and hGH, and also controlled by somatostatin (Clements and Elias, 1985; Kraenzlin et al., 1985 ; Schulter et al., 1983; Spinas et al., 1984). 
In this study, we have not determined the glucagon levels. Our observations on the blood glucose profile might be the result of a combination of these factors.

We conclude that SMS 201-995 is a potent somatostatin analogue in suppressing the GH secretion in acromegaly in the acute phase. However, the optimal dose, the optimal number of administrations, or a less painful injection route should be considered for the clinical management of acromegaly.

\section{Acknowlegements}

The authors are greatly indebted to Sandoz Pharmaceutical Co., Ltd. (Basel, Switzerland) for supplying somatostatin analogue, SMS 201995.

This work was partly supported by Grants in Aid for Scientific Research from the Ministry of Education, Science and Culture, Japan (No. 61440052, No. 61570566, and No. 61770872), a Research Grant from the Intractable Disease Division, Public Health Bureau, Ministry of Health and Welfare, and a Research Grant from the Foundation for Growth Science in Japan.

\section{References}

Althoff, P. H., B. Boettger, C. Rosak, M. Neufeld, F. Lacey, H. Knigge, W. Magnet, E. Jungmann and K. Schöffleng (1984). Influence of a long-acting somatostatin analogue (SMS 201-995) in acromegalic patients. Acta Endocrinol. 105, Suppl. 264, 29.

Bauer, W., U. Briner, W. Doepfner, R. Haller, R. Huguenin, P. Marbach, T. J. Petcher and J. Pless (1982 a). SMS 201-995: A very potent and selective octapeptide analogue of somatostatin with prolonged action. Life Sci. 31, 1133-1140.

Bauer, W., U. Briner, W. Doepfner, R. Haller, R. Huguenin, P. Marbach, T. J. Petcher and J. Pless $(1982$ b). Structure-activity relationships of highly potent and specific octapeptide analoguès of somatostatin. Peptides, 582-588.

Besser, G. M., C. H. Mortimer, D. Carr, A. V. Schally, D. H. Coy, D. Evered, A. J. Kastin,
W. M. G. Tunbridge, M. O. Thorner and R. Hall (1974). Growth hormone release inhibiting hormone in acromegaly. $B r . M e d . J .1$, 352-355.

Bloom, S. R., L. J. C. Ch'ng, S. M. Wood, M. Kraenzlin and S. J. Williams (1984). Effect of chronic administration of a long-acting somatostatin analogue on glucose homeostasis. Diabetologia 27, 47A, (Abstract).

Ch'ng, L. J. C., S. M. Sandler, M. E. Kraenzlin, J. M. Burrin, G. F. Joplin and S. R. Bloom (1985). Long term treatment of acromegaly with a long acting analogue of somatostatin. Br. Med. J. 290, 284-285.

Clements, D. and E. Elias (1985). Regression of metastatic vipoma with somatostatin analogue SMS 201-995. Lancet 4, 874-875.

Kraenzlin, M. E., S. M. Wood, M. Neufeld, T. E. Adrian and S. R. Bloom (1985). Effect of long-acting somatostatin analogue SMS 201995 on gut hormone secretion in normal subjects. Experientia 41, 738-740.

Lamberts, S. W. J., P. Uitterlinden, L. Verschoor, K. J. Van Dongen and E. Del Pozo (1985 a). Long-term treatment of acromegaly with the somatostatin analogue SMS 201-995. N. Engl. J. Med. 313, 1576-1580.

Lamberts, S. W. J., R. Oosterom, M. Neufeld and E. Del Pozo (1985 b). The somatostatin analog SMS 201-995 induces long-acting inhibition of growth hormone secretion without rebound hypersecretion in acromegalic patients. J. Clin. Endocrinol. Metab. 60, 1161-1165.

Mayer, G. and H. Tillil (1984). Effect of the somatostatin analog SMS 201-995 on GHand PRL-secretion in patients with acromegaly. Acta Endocrinol. 105, Suppl. 264, 31.

Miyakawa, M., N. Hizuka, K. Takano, I. Tanaka, N. Honda, R. Horikawa and K. Shizume (1986). Radioimmunoassay for insulin-like growth factor I (IGF-I) using biosynthetic IGFI. Endocrinol. Japon. 33, (No. 1642).

Plewe, G., J. Beyer, U. Krause, M. Neufeld and E. Del Pozo (1984 a). Long-acting and selective suppression of growth hormone secretion by somatostatin analogue SMS 201-995 in acromegaly. Lancet 2, 782-784.

Plewe, G., M. Neufeld, U. Krause, D. Oppermann and $H$. Beyer (1984 b). Suppression of $\mathrm{GH}$-secretion to normal value by a long-acting analogue of somatostatin in acromegaly. Acta Endocrinol. 105, Suppl. 264, 30.

Plewe, G., G. Nölken, U. Krause, E. Del Pozo 
and J. Beyer (1984 c). Suppression of growth hormone and somatomedin $\mathrm{C}$ secretion by long-acting somatostatin analogue (SMS 201995) in type 1 (insulin dependent) diabetes. Diabetologia 27, 419A. (Abstract).

Plewe, G., G. Nölken, E. Kustner, E. Del Pozo, G. Kahaly, U. Krause and J. Beyer (1984 d). Reduction of growth hormone and somatomedin $\mathrm{C}$ secretion by long-acting somatostatin analogue SMS 201-995 in type 1 diabetics. Diabetes 33, Suppl. 1, 97A. (Abstract).

Schulter, K. J., P. Marbach, E. Del Pozo and L. Kerp (1983). Receptor binding of new modified potent and selective somatostatin (SMS 201-995). Diabetes 32, Suppl. 1, 135A. (Abstract).

Shibasaki, T., Y. Kiyosawa, A. Masuda, M. Na- kahara, T. Imaki, I. Wakabayashi, H. Demura, K. Shizume and N. Ling (1984). Distribution of growth hormone-releasing hormone-like immunoreactivity in human tissue extracts. $J$. Clin. Endocrinol. Metab. 59, 263-268.

Spinas, G. A., U. Keller, L. Varga and M. Neufeld (1984). Reduction of postprandial hyperglycemia and suppression of gastrointestinal hormones after s.c. administration of a new somatostatin analogue in type 1 diabetics. Eur. J. Clin. Invest. 14, 142.

Von Werder, K., M. Losa, O. A. Müller, L. Schweiberer, R. Fahlbusch and E. Del Pozo (1984). Treatment of metastatic GRF-producing tumor with a long-acting somatostatin analogue. Lancet 8, 282. 